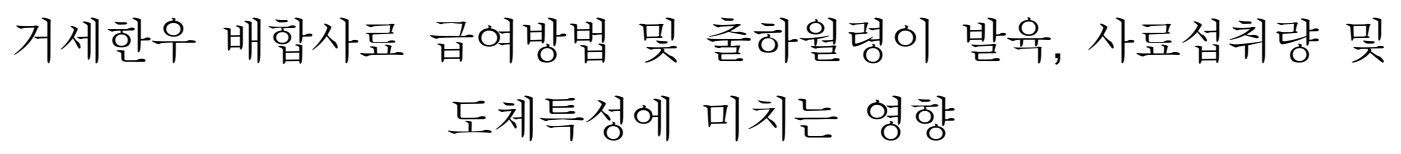

조영무 · 장선식・김형철・김태일・박병기・백봉현 · 김진형·권응기

농촌진흥청 국립축산과학원

\title{
Effects of Concentrate Feeding Method and Slaughter Age on Growth Performance, Feed Intake and Carcass Characteristics of Hanwoo Steers
}

Young Moo Cho, Sun Sik Chang, Hyeong Cheol Kim, Tae Il Kim, Byung Ki Park, Bong Hyun Paek, Jin Hyoung Kim and Eung Gi Kwon

National Institute of Animal Science, RDA

\begin{abstract}
Thirty one Hanwoo steers were used in a completely randomized design experiment to see the effects of concentrate feeding method (group vs. individual feeding) and age at slaughter (26 vs. 28 months of age) on growth performance, feed intake and carcass characteristics. Steers were randomly assigned to one of four groups, G26 (group feeding slaughtered at 26 months of age), G28 (group feeding slaughtered at 28 months of age), I26 (individual feeding slaughtered at 26 months of age) or I28 (individual feeding slaughtered at 28 months of age). Amount of concentrate were restricted to $1.5 \%$ of BW for the growing period and $1.8 \%$ of BW for the early fattening period in both groups. For the late fattening period, concentrate were given ad libitum for G26 and G28, but were given up to $1.7 \%$ of BW for I26 and I28. Average daily gains were higher in individual feeding groups (I26 and I28) than those in group feeding groups (G26 and G28) for the early fattening period $(\mathrm{p}<0.05)$. ADGs were higher in group feeding groups than those in individual feeding groups $(p<0.05)$. Concentrate intake in individual feeding groups tended to be higher compared to that in group feeding groups for the early fattening period, but tended to be higher in group feeding groups compared to that in individual feeding groups for the late fattening period. Feeding method or slaughter age had no significant effects on carcass characteristics, yield grade and quality grade. Shear force and tenderness of longissmus muscle were higher in groups slaughtered at 28 months of age than in groups slaughtered at 26 months of age $(\mathrm{p}<0.05)$. Feeding method or slaughter age had no effects on cooking loss, water holding capacity, juiciness, flavor, moisture, protein and fat of longissmus muscle.
\end{abstract}

(Key words : Hanwoo steer, Feeding method, Age at slaughter, Carcass characteristics)

\section{I. 서 론}

최근 미국산 쇠고기의 수입 재개 및 FTA 추진 확 대 등으로 대외 개방이 가속화되고 있으며, 국제 곡물 가격의 급등에 따른 사료비 지속 인상으로 한우산업 의 어려움은 나날이 커져가고 있다. 이러한 시점에서 수입육에 비해 가격 경쟁력이 열악한 한우는 품질고 급화를 통한 수입육과의 차별화가 필요한데, 한우 품 질고급화를 목적으로 거세한우의 비육기간이 장기화 됨에 따라 ' 07 년 육질 1 등급 이상 출현률은 $71.5 \%$, 육 량 $\mathrm{A}$ 등급 출현률은 $32.6 \%$ (축산물등급판정소, 2008)로
이제는 육질등급 뿐만 아니라 육량등급도 고려하여 배합사료 이용효율을 증진시킬 수 있는 경제적인 사 양기술 개발이 요구된다.

비육후기 사료급여 방법은 산육능력, 사료효율 및 경제성에 영향을 미치는 중요한 요인이므로 (Andersen 과 Ingvartsen, 1984; Hermesmeyer 등, 2002), 거세와 비 육기간 연장에 따른 생산비를 절감시키기 위해서는 비육단계별로 사료급여량을 효율적으로 조절해야 할 필요성이 있다.

거세우에서 일정기간의 배합사료 제한급여는 사료 섭취량 감소로 일당증체량을 감소시키는 단점이 있지

Corresponding author : Eung Gi Kwon, Hanwoo Experiment Station, National Institute of Animal Science, RDA. Tel: 033-330-0612, Fax: 033-330-0660, E-mail: kug2237@rda.go.kr 
만 (Hermesmeyer 등, 2002), 건물 및 유기물 소화율 (Murphy 등, 1994)과 영양소의 이용성 (Hermesmeyer 등, 2000)을 개선하여 사료효율 (Hicks 등, 1990)이 향 상될 뿐만 아니라 사료비를 포함한 생산비용 (Loerch 와 Fluharty, 1998)도 줄일 수 있는 것으로 보고된 바 있다.

김 등 (2003)은 거세한우의 비육후기 동안 배합사료 를 체중의 $1.7 \%$ 로 제한급여시 자유채식구에 비해 육 질 1 등급 이상 출현률이 $20 \%$ 정도 높아질 뿐만 아니 라 배합사료비도 절감되었다고 보고한 바 있으나, 군 사조건하에서는 배합사료의 제한급여시 개체간 우열 의 차이로 인해 힘이 약한 개체들은 배합사료를 제대 로 섭취하지 못하는 문제가 발생되기 때문에 모든 개 체들이 정해진 양의 배합사료를 골고루 섭취할 수 있 는 사양관리 기술이 필요하다.

따라서 본 연구는 개체별 배합사료 자동급이기를 이용한 배합사료의 제한급여 (특히 비육후기) 및 출하 월령 (비육기간)이 거세한우의 발육, 사료섭취량 및 도 체특성 변화에 미치는 영향을 검토하여 거세한우를 대상으로 개체별 배합사료 자동급이기의 적용시 활용 가능한 기초자료를 확보하기 위해 수행되었다.

\section{ㅍ. 재료 및 방법}

\section{1. 공시동물 및 시험기간}

본 연구는 평균체중 $204.2 \mathrm{~kg}( \pm 18.0 \mathrm{~kg})$ 의 생후 약 8 개월령 거세한우 31 두를 공시하여 생후 8 개월령부터 28 개월령까지 22 개월간 수행하였다.

\section{2. 시험설계}

시험구 배치는 생후 26개월령 출하 군사구 (G26),
개체별 배합사료 자동급이구(I26), 생후 28개월령 출 하 군사구 $(\mathrm{G} 28)$, 개체별 배합사료 자동급이구 (I28)의 4처리로 하여 각 처리당 7 8두씩 (G26, I26 및 $\mathrm{G} 28=8$ 두, $\mathrm{I} 28=7$ 두) 총 31 두를 완전 임의배치하였다.

\section{3. 시험사료 및 사양관리}

시험사료는 시판 배합사료와 볏짚을 이용하였으며 (Table 1), 배합사료 급여방법 (군사, 개체별 배합사료 자동급이) 및 출하월령 (생후 26 및 28개월)에 관계없 이 육성기와 비육전기 배합사료 급여량은 각각 체중 의 $1.5 \%$ 및 $1.8 \%$ 로 제한하였다. 비육후기 동안 군사 구 (G26 및 G28)는 배합사료를 자유채식시켰고, 개체 별 배합사료 자동급이구는 개체별로 체중의 $1.7 \%$ 로 제한하였다. 볏짚은 전기간 자유채식시켰으며, 물과 미네랄 블록은 항상 자유롭게 이용 가능토록 하였다.

\section{4. 조사항목 및 조사방법}

체중은 시험 개시시부터 종료시까지 1 개월 간격으 로 개체별로 조사하였으며, 사료섭취량은 매일 오전 사료 급여전에 잔량을 측정하여 급여량에서 잔량을 공제하여 계산하였다. 도체조사는 사양시험이 종료된 공시축을 서울공판장으로 출하하여 도축한 후, $0^{\circ} \mathrm{C}$ 에 서 18 24시간 동안 도체를 현수시킨 후 육량판정요 인 (도체중, 등지방두께, 배최장근단면적)과 육질판정 요인 (근내지방도, 육색, 지방색, 조직감, 성숙도)을 소 도체등급판정기준에 의거하여 축산물등급판정사가 평 가하였다. 전단력은 등심을 스테이크 모양으로 절단하 여 심부온도 $70^{\circ} \mathrm{C}$ 에서 10 분간 가열한 후 전단력 측정 기 (Warner-Bratzler shear meter; G-R Elec. Mfg. Co., USA)로 측정하였고, 가열감량은 배최장근의 가열 전. 후의 중량차로 계산하였으며, 보수력은 Laakkonen 등

Table 1. Chemical composition of experimental diets (as-fed basis)

\begin{tabular}{lcccc}
\hline \multirow{2}{*}{ Item } & \multicolumn{3}{c}{ Concentrate } & \multirow{2}{*}{ Rice straw } \\
\cline { 2 - 4 } & Growing & Early fattening & Late fattening & \\
\hline \hline Moisture (\%) & 12.73 & 13.98 & 13.22 & 14.69 \\
Crude protein (\%) & 14.25 & 11.73 & 12.56 & 3.62 \\
Ether extract (\%) & 3.23 & 3.40 & 3.91 & 1.41 \\
Crude fiber (\%) & 8.70 & 7.97 & 8.17 & 32.45 \\
Crude ash (\%) & 5.98 & 5.06 & 5.62 & 11.68 \\
$\mathrm{Ca}(\%)$ & 1.33 & 1.02 & 0.75 & 0.16 \\
$\mathrm{P}(\%)$ & 0.55 & 0.40 & 0.34 & 0.08 \\
\hline
\end{tabular}


(1970)의 방법에 준하여 측정하였다. 등심의 화학성분 은 $\mathrm{AOAC}(1995)$ 방법에 준하여 분석하였다. 관능검사 는 검사요원 10 명을 무작위로 차출하여 처리별로 다 즙성, 연도, 향미에 대하여 기호도 6점 만점의 순위법 에 의하여 조사하였다.

\section{5. 통계처리}

본 시험에서 얻어진 성적들은 SAS package (1999)를 이용하여 분산분석 및 처리구간 유의성 $(\mathrm{p}<0.05)$ 을 검 증하였다.

\section{III. 결과 및 고찰}

배합사료 급여방법 및 출하월령이 육성기 거세한우 의 발육에 미치는 영향은 없었다 (Table 2). 처리에 관 계없이 배합사료를 체중의 $1.8 \%$ 로 급여한 결과, 비육 전기 증체에 대한 출하월령의 영향은 없었지만, 출하 월령에 관계없이 군사구들 $(\mathrm{G} 26$ 및 $\mathrm{G} 28)$ 에 비해 개체 별 배합사료 자동급이구들 (I26 및 I28)에서 일당증체
량이 유의적으로 높았다 $(\mathrm{p}<0.05)$. 비육후기 동안에는 배합사료의 자유채식이 이루어졌던 군사구들이 제한 급여 (체중의 $1.7 \%$ 수준)가 이루어졌던 개체별 배합사 료 자동급이구들에 비해 일당증체량이 유의적으로 높 았으며 $(\mathrm{p}<0.05)$, 비육전기와 마찬가지로 비육후기 증 체에 대한 출하월령의 영향은 없었다.

본 연구에서 비육전기 동안 일당증체량이 군사구들 에 비해 개체별 배합사료 자동급이구들에서 높았던 원인은 비록 배합사료의 급여 수준은 체중의 $1.8 \%$ 로 동일하였지만, 개체별 배합사료 자동급이구들의 경우 군사구들에 비해 개체간 우열에 영향을 받지 않고 모 든 개체가 안정적으로 정해진 양의 배합사료를 섭취 할 수 있었기 때문인 것으로 판단된다. 실제로 비육전 기 동안 군사구들에 비해 개체별 배합사료 자동급이 구들에서 출하월령별로 배합사료 섭취량은 높은 반면 에 조사료 섭취량은 낮은 결과를 통해 알 수 있듯이 군사구들의 경우 개체간 우열의 차이로 인해 배합사 료 섭취량이 부족한 일부 개체들이 영양가치가 낮은 볏짚을 더 많이 섭취함에 따라 증체량이 낮았던 것으 로 사료된다 (Table 3).

Table 2. Effects of concentrate feeding method and slaughter age on growth performance of Hanwoo steers

\begin{tabular}{|c|c|c|c|c|c|c|c|}
\hline \multirow{2}{*}{ Item } & \multirow{2}{*}{ G26 ${ }^{1)}$} & \multirow{2}{*}{$\mathrm{I} 26^{2)}$} & \multirow{2}{*}{$\mathrm{G} 28^{3)}$} & \multirow{2}{*}{$\mathrm{I} 28^{4)}$} & \multirow{2}{*}{$\mathrm{SEM}^{5)}$} & \multicolumn{2}{|c|}{ Significance ( $\mathrm{P}$ value) } \\
\hline & & & & & & $\mathrm{CFM}^{6}$ & $\mathrm{SA}^{7)}$ \\
\hline \multicolumn{8}{|l|}{ Growing period } \\
\hline Initial $\mathrm{BW}^{8)}(\mathrm{kg})$ & 203.6 & 203.8 & 203.8 & 205.9 & 3.2 & 0.88 & 0.88 \\
\hline Final BW (kg) & 291.0 & 295.6 & 285.3 & 279.9 & 6.3 & 0.81 & 0.28 \\
\hline $\mathrm{ADG}^{9)}(\mathrm{kg} / \mathrm{d})$ & 0.72 & 0.76 & 0.67 & 0.55 & 0.04 & 0.65 & 0.09 \\
\hline \multicolumn{8}{|l|}{ Early fattening period } \\
\hline Initial BW (kg) & 291.0 & 295.6 & 285.3 & 279.9 & 6.3 & 0.81 & 0.28 \\
\hline Final BW (kg) & 473.1 & 510.9 & 468.6 & 484.4 & 9.1 & 0.13 & 0.39 \\
\hline ADG (kg/d) & 0.75 & 0.88 & 0.75 & 0.87 & 0.02 & 0.02 & 0.83 \\
\hline \multicolumn{8}{|l|}{ Late fattening period } \\
\hline Initial BW (kg) & 473.1 & 510.9 & 468.6 & 484.4 & 9.1 & 0.13 & 0.39 \\
\hline Final BW (kg) & 664.9 & 635.9 & 680.5 & 637.4 & 11.9 & 0.13 & 0.68 \\
\hline $\mathrm{ADG}(\mathrm{kg} / \mathrm{d})$ & 1.04 & 0.68 & 0.86 & 0.62 & 0.04 & $<0.0001$ & 0.15 \\
\hline \multicolumn{8}{|l|}{ Whole period } \\
\hline Initial BW (kg) & 203.6 & 203.8 & 203.8 & 205.9 & 3.2 & 0.88 & 0.88 \\
\hline Final BW (kg) & 664.9 & 635.9 & 680.5 & 637.4 & 11.9 & 0.13 & 0.68 \\
\hline ADG (kg/d) & 0.84 & 0.79 & 0.78 & 0.71 & 0.02 & 0.09 & 0.07 \\
\hline
\end{tabular}

${ }^{1)}$ G26 : group feeding slaughtered at 26 months age; ${ }^{2)}$ I26 : individual feeding slaughtered at 26 months of age;

${ }^{3)}$ G28 : group feeding slaughtered at 28 months age; ${ }^{4)}$ I28: individual feeding slaughtered at 28 months of age;

${ }^{5)}$ SEM : standard error of mean; ${ }^{6)} \mathrm{CFM}$ : concentrate feeding method; ${ }^{7)} \mathrm{SA}$ : slaughter age; ${ }^{8)} \mathrm{BW}$ : body weight;

9) $\mathrm{ADG}$ : average daily gain. 
Table 3. Effects of concentrate feeding method and slaughter age on feed intakes of Hanwoo steers

\begin{tabular}{|c|c|c|c|c|}
\hline Item & G26 & $\mathrm{I} 26$ & $\mathrm{G} 28$ & $\mathrm{I} 28$ \\
\hline \multicolumn{5}{|l|}{ Feed intake (kg/day) } \\
\hline \multicolumn{5}{|l|}{ Growing period } \\
\hline Concentrates & 3.06 & 3.00 & 3.07 & 2.61 \\
\hline Rice straw & 2.75 & 2.21 & 2.76 & 2.49 \\
\hline $\mathrm{DMI}^{1)}$ & 5.82 & 5.21 & 5.83 & 5.10 \\
\hline \multicolumn{5}{|l|}{ Early fattening } \\
\hline Concentrates & 5.66 & 5.79 & 5.50 & 5.55 \\
\hline Rice straw & 3.01 & 2.01 & 3.07 & 2.83 \\
\hline DMI & 8.67 & 7.80 & 8.57 & 8.38 \\
\hline \multicolumn{5}{|l|}{ Late fattening } \\
\hline Concentrates & 9.11 & 8.82 & 9.18 & 9.00 \\
\hline Rice straw & 1.10 & 1.65 & 1.37 & 2.45 \\
\hline DMI & 10.21 & 10.47 & 10.55 & 11.45 \\
\hline \multicolumn{5}{|l|}{ Whole period } \\
\hline Concentrates & 6.23 & 6.18 & 6.49 & 6.34 \\
\hline Rice straw & 2.32 & 1.93 & 2.33 & 2.61 \\
\hline DMI & 8.55 & 8.11 & 8.81 & 8.95 \\
\hline \multicolumn{5}{|l|}{ Feed conversion $(\mathrm{kg} / \mathrm{kg})$} \\
\hline Growing period & 8.08 & 6.20 & 8.70 & 9.28 \\
\hline Early fattening period & 11.56 & 8.96 & 11.42 & 9.63 \\
\hline Late fattening period & 9.82 & 16.10 & 12.27 & 18.47 \\
\hline Whole period & 10.18 & 10.27 & 11.30 & 12.61 \\
\hline
\end{tabular}

1) DMI : dry matter intake.

본 실험에서 출하월령에 관계없이 비육후기 동안 배합사료 자유채식구에 비해 제한급여구 (개체별 배합 사료 자동급이구)에서 일당증체량이 낮았던 결과는 거 세한우의 비육후기 (생후 19 28개월) 동안 배합사료를 체중의 $1.7 \%$ 로 제한급여 시킨 결과 자유채식구에 비 해 일당증체량과 출하체중이 낮았다는 김 등 (2003)의 결과와 유사한 경향을 보였는데, 비육후기 증체량이 배합사료 제한급여구에 비해 군사구들에서 높았던 원 인은 배합사료 섭취량의 차이에서 비롯된 것으로 판 단된다. 군사구들의 경우 비육후기 동안에는 배합사료 의 자유채식이 이루어진 반면에 개체별 배합사료 자 동급이구들의 경우에는 여전히 제한급여가 이루어짐 으로 인해 증체를 위한 에너지 및 영양소 공급이 부 족되어 증체량이 낮았던 것으로 사료된다. 실제로 거 세우에서 비육후기 배합사료의 제한급여는 자유채식 에 비해 일당증체량이 감소되고 동일한 체중에 도달 되는 사육기간이 증가되므로 (Loerch, 1990; Murphy
등, 1994) 개체별 배합사료 자동급이기를 거세한우에 적용시 개체 특성에 대한 고려 없이 일률적인 배합사 료의 제한급여 보다는 비육후기 동안 일정한 간격의 초음파 단층촬영을 통해 개체 특성 (등지방두께, 근내 지방도 등)을 고려하여 배합사료 급여량을 개체별로 달리 설정하여 정상적인 증체와 근내지방 합성을 위 한 에너지 및 영양소 공급이 부족하지 않도록 해줄 필요가 있을 것으로 판단된다.

육성기 배합사료, 조사료 및 건물섭취량은 군사구들 에 비해 개체별 배합사료 자동급이구들에서 약간 적 었다 (Table 3). 비육전기 배합사료 섭취량은 군사구들 에 비해 개체별 배합사료 자동급이구들에서 많았지만, 상대적으로 조사료 섭취량이 적어 군사구들에 비해 건물섭취량은 적었다. 그러나 비육후기에는 배합사료 의 자유채식이 이루어졌던 군사구들이 제한급여가 이 루어졌던 개체별 배합사료 자동급이구들에 비해 배합 사료 섭취량이 26 및 28 개월 출하구에서 각각 3.2 및 
$2.0 \%$ 정도 많았다. 한편 비육전기와는 반대로 개체별 배합사료 자동급이구들에서 군사구들에 비해 조사료 섭취량이 26 및 28 개월 출하구에서 각각 33.3 및 $44.0 \%$ 정도 많았으며, 이로 인해 건물섭취량은 군사구 들에 비해 개체별 배합사료 자동급이구들에서 많았다. 한편 비육전기 사료요구율은 출하월령에 관계없이 군 사구들에 비해 개체별 배합사료 자동급이구들에서 낮 았으나, 비육후기 사료요구율은 군사구들에 비해 개체 별 배합사료 자동급이구들 (배합사료 제한급여구)에서 높았다.

본 연구에서 비육전기 동안 출하월령별로 군사구들 에 비해 개체별 배합사료 자동급이구들에서 배합사료 섭취량은 많은 반면에 조사료 섭취량이 적었고, 비육 후기 동안에는 출하월령별로 군사구들에 비해 개체별 배합사료 자동급이구들 (배합사료 제한급여구)에서 배 합사료 섭취량은 적은 반면에 조사료 섭취량은 많았 던 원인은 배합사료 급여 방법 및 급여 수준의 차이 에서 비롯된 것으로 판단된다. 비육전기에는 군사구들 에 비해 개체간 우열의 차이가 발생하지 않았던 개체 별 배합사료 자동급이구들에서 모든 개체들이 정해진 양의 배합사료를 골고루 섭취를 할 수 있었기 때문인 것으로 생각되며, 비육후기에는 군사구들의 경우 배합 사료의 자유채식이 이루어짐으로 힘이 약한 개체들도 충분한 양의 배합사료를 섭취할 수 있었던 반면에 개 체별 배합사료 자동급이구의 경우에는 제한급여가 유 지됨으로 인해 상대적으로 볏짚의 섭취량이 증가했던
것으로 사료된다.

거세한우에서 비육후기 배합사료의 적절한 공급은 증체 및 근내지방 합성을 위한 가장 중요한 영양소 및 에너지 공급원이다. 본 연구에서 개체별 배합사료 자동급이구의 경우 비육후기 동안 개체별 특성에 대 한 고려 없이 일률적으로 배합사료의 제한급여가 이 루어짐으로 인해 군사구에 비해 증체 (Table 2) 및 근 내지방도(Table 4) 증가의 효과가 적었다. 이러한 결 과를 통해 실제 거세한우 사육농가에서 개체별 배합 사료 자동급이기를 이용할 경우 비육후기 배합사료의 급여수준은 기본적으로 자유채식 수준에 상응하는 조 건하에서 단지 초음파 단층촬영을 통해 개체별 육질 및 육량 관련 특성을 고려하여 배합사료의 제한급여 가 필요한 개체에 한해서 배합사료 섭취량을 조절해 주는 것이 바람직 할 것으로 사료된다.

사료급여 방법 및 출하월령이 거세한우의 배최장근 단면적, 등지방두께 및 육량등급에 미치는 영향은 없 었으며 (Table 4), 근내지방도, 육색, 지방색, 조직감 및 육질등급에 미치는 영향도 적었다. 다만 예상대로 성 숙도는 배합사료의 급여방법에 관계없이 생후 26 개월 출하 시험구들에 비해 28 개월령 출하 시험구들에 높 았다 $(\mathrm{p}<0.05)$.

본 연구에서 배합사료 급여방법이 거세한우의 육질, 육량 관련 특성에 미치는 영향은 적었지만, 출하월령 별로 군사구들 $(\mathrm{G} 26$ 및 $\mathrm{G} 28)$ 에 비해 개체별 배합사료 자동급이구들 (I26 및 $\mathrm{I} 28$ )에서 근내지방도가 낮은 경

Table 4. Effects of concentrate feeding method and slaughter age on carcass characteristics of Hanwoo steers

\begin{tabular}{|c|c|c|c|c|c|c|c|}
\hline \multirow{2}{*}{ Item } & \multirow{2}{*}{ G26 } & \multirow{2}{*}{$\mathrm{I} 26$} & \multirow{2}{*}{$\mathrm{G} 28$} & \multirow{2}{*}{$\mathrm{I} 28$} & \multirow{2}{*}{ SEM } & \multicolumn{2}{|c|}{ Significance (P value) } \\
\hline & & & & & & CFM & SA \\
\hline \multicolumn{8}{|l|}{ Quantity traits ${ }^{1)}$} \\
\hline Longissmus muscle area $\left(\mathrm{cm}^{2}\right)$ & 89.50 & 86.63 & 93.75 & 89.33 & 1.76 & 0.26 & 0.33 \\
\hline Back fat thickness (mm) & 7.63 & 9.00 & 8.25 & 8.50 & 0.53 & 0.92 & 0.44 \\
\hline Yield grade (A:B:C, head) & $7: 1: 0$ & $7: 1: 0$ & $7: 1: 0$ & $6: 1: 0$ & - & - & - \\
\hline \multicolumn{8}{|l|}{ Quality traits ${ }^{2)}$} \\
\hline Marbling score & 4.63 & 4.50 & 4.88 & 4.57 & 0.29 & 0.73 & 0.79 \\
\hline Meat color & 5.00 & 5.00 & 4.88 & 5.00 & 0.03 & 0.37 & 0.31 \\
\hline Fat color & 3.00 & 3.00 & 2.88 & 2.71 & 0.05 & 0.44 & 0.06 \\
\hline Texture & 1.25 & 1.25 & 1.25 & 1.29 & 0.08 & 0.92 & 0.92 \\
\hline Maturity & 2.00 & 2.00 & 3.00 & 3.00 & 0.09 & - & $<0.0001$ \\
\hline Quality grade $\left(1^{++}: 1^{+}: 1: 2: 3\right.$, head $)$ & $0: 3: 3: 2: 0$ & $0: 2: 4: 2: 0$ & $0: 4: 2: 2: 0$ & $0: 2: 3: 2: 0$ & - & - & - \\
\hline
\end{tabular}

\footnotetext{
1) Area was measured from longissimus muscle taken as $13^{\text {th }}$ rib and back fat thickness were also measured at $13^{\text {th }}$ rib.

${ }^{2)}$ Grading ranges are 1 to 9 for marbling score with higher numbers for better quality $(1=$ devoid, $9=$ abundant $)$; meat color $(1$ $=$ brightly cherry red, $7=$ extremely dark red $)$; fat color $(1=$ white, $7=$ dark yellow $)$; texture $(1=$ soft, $3=$ firm $)$; Maturity ( 1 = youthful, $9=$ mature).
} 
향을 보였을 뿐만 아니라 28개월 출하 개체별 배합사 료 자동급이구의 근내지방도는 26 개월 출하 군사구에 비해서도 낮은 경향을 보임으로 인해 비육후기 왕성 한 근내지방의 침착을 위한 적절한 배합사료 공급의 중요성을 재차 확인할 수 있었던 것으로 판단된다. 단 지 본 연구에서 사료급여 방법에 관계없이 생후 26 개 월 출하구들과 28 개월 출하구들간의 육량 및 육질 등 급에 차이가 적은 결과를 통해 배합사료 가격이 지속 적으로 올라가는 현 시점에서 출하월령 증가에 따른 육량, 육질 특히 육질 향상의 효율성을 감안할 때 거 세한우의 비육기간 조정도 필요할 것으로 사료된다.

김 등 (2003)은 거세한우의 비육후기 (생후 19 28개 월) 동안 배합사료를 체중의 $1.7 \%$ 로 제한급여 시킨 결과 자유채식구에 비해 육질 1 등급 이상 출현두수가 2 두 많았을 뿐 배최장근단면적, 등지방두께, 근내지방 도 등 도체특성의 차이는 없었다고 보고한 바 있는데, 본 연구에서도 출하월령별 비육후기 배합사료 급여수 준이 거세한우의 육질 및 육량관련 특성 변화에 미치 는 영향은 적었지만, 출하체중의 차이에 따른 도체가 격의 차이가 발생하는 문제가 있었다. 따라서 개체별 배합사료 자동급이기를 거세한우에 적용시 비육후기 동안 일률적인 배합사료의 제한급여 보다는 개체별 육질 및 육량관련 특성을 고려하여 배합사료 급여량 을 개체별로 달리 설정해 줄 필요가 있을 것으로 판 단된다.

배최장근의 전단력에 대한 사료급여 방법의 영향은 없었으나(Table 5), 26개월 출하 시험구들에 비해 28
개월 시험구들에서 전단력이 높았다 $(p<0.05)$. 배최장 근의 가열감량과 보수력에 대한 배합사료 급여방법 및 출하월령의 영향은 없었다. 배최장근의 다즙성에 대한 배합사료 급여방법 및 출하월령의 영향은 없었 으나, 연도는 배합사료 급여방법에 관계없이 26 개월 출하 시험구들에 비해 28개월 출하 시험구들에서 높 았다 $(\mathrm{p}<0.05)$. 배최장근의 풍미는 연도와 유사하게 배 합사료 급여방법에 의한 영향 없이 26개월 출하 시험 구들에 비해 28 개월 출하 시험구들에서 높은 경향을 보였으나, 통계적인 유의차이는 없었다. 한편, 배최장 근의 수분, 단백질 및 지방 함량에 대한 배합사료 급 여방법 및 출하월령의 영향은 없었다.

본 연구에서 다즙성과 풍미에 대한 배합사료 급여 방법 및 출하월령의 영향은 크지 않았으나, Shackelford 등 (1995)은 근내지방도가 높을수록 다즙성이 증가한 다고 보고한 바 있는데, 본 연구에서는 처리간 근내지 방도의 차이가 크지 않았기 때문에 처리간 다즙성이 유사했던 것으로 판단된다. 또한 본 연구에서는 풍미 의 경우 26 개월 출하 시험구들에 비해 28개월 출하 시험구들에서 약간 높은 경향을 보이기는 하였으나, 2 개월의 비육기간 차이가 거세한우의 풍미 증가에 미 치는 영향은 적은 것으로 판단된다. 한편, 연도는 26 개월 출하 시험구들에 비해 28 개월 출하 시험구들에 서 높았는데, 육질등급 (근내지방도)이 높을수록 연도 가 우수했다는 Shackelford 등 (1995)의 연구결과와 비 교할 경우 본 연구에서는 26 개월 출하 시험구와 28 개 월 출하 시험구간에 근내지방도의 차이가 크지 않았

Table 5. Effects of concentrate feeding method and slaughter age on physical characteristics and chemical composition in longissmus muscle of Hanwoo steers

\begin{tabular}{|c|c|c|c|c|c|c|c|}
\hline \multirow{2}{*}{ Item } & \multirow{2}{*}{ G26 } & \multirow{2}{*}{ I 26} & \multirow{2}{*}{ G28 } & \multirow{2}{*}{$\mathrm{I} 28$} & \multirow{2}{*}{ SEM } & \multicolumn{2}{|c|}{ Significance (P value) } \\
\hline & & & & & & CFM & $\mathrm{SA}$ \\
\hline \multicolumn{8}{|l|}{ Physical characteristics } \\
\hline Shear force $\left(\mathrm{kg} / \mathrm{cm}^{2}\right)$ & 3.92 & 3.74 & 4.37 & 4.31 & 0.12 & 0.63 & 0.02 \\
\hline Cooking loss (\%) & 21.36 & 21.79 & 18.83 & 22.24 & 0.55 & 0.09 & 0.33 \\
\hline Water holding capacity (\%) & 57.17 & 58.49 & 57.08 & 56.67 & 0.32 & 0.46 & 0.15 \\
\hline \multicolumn{8}{|l|}{ Panel test ${ }^{1)}$} \\
\hline Juiciness & 4.70 & 4.65 & 4.53 & 4.50 & 0.08 & 0.77 & 0.27 \\
\hline Tenderness & 4.05 & 4.09 & 4.56 & 4.71 & 0.11 & 0.68 & 0.01 \\
\hline Flavor & 4.48 & 4.64 & 4.81 & 4.73 & 0.06 & 0.76 & 0.07 \\
\hline \multicolumn{8}{|l|}{ Chemical composition (\%) } \\
\hline Moisture & 65.85 & 66.06 & 65.14 & 64.63 & 0.49 & 0.88 & 0.29 \\
\hline Protein & 20.33 & 20.20 & 20.17 & 20.13 & 0.20 & 0.82 & 0.76 \\
\hline Fat & 13.04 & 11.94 & 12.55 & 13.63 & 0.67 & 0.99 & 0.68 \\
\hline
\end{tabular}

${ }^{1)}$ Panel test score : 1 (very bad) to 5 (very good). 
음에도 불구하고 연도의 차이가 발생하여 배최장근의 연도에 비육기간이 일정부분 영향을 미치는 것으로 판단된다. 배최장근의 지방산 조성 및 함량을 분석하 지는 않았으나, 비록 근내지방 혹은 등심의 지방 함량 이 유사한 수준이더라도 비육기간 증가에 따른 일부 지방산 조성 및 함량의 차이도 배최장근의 연도에 영 향을 미칠 것으로 생각되지만 이에 대한 추가적인 연 구가 있어야 할 것으로 판단된다.

따라서 본 연구에서 출하월령 차이가 배최장근의 전단력 및 연도에 미치는 영향은 있었으나, 육질 및 육량 관련 특성 변화에 미치는 영향은 크지 않는 것 으로 판단된다. 한편, 비육후기 개체별 배합사료의 급 여수준이 거세한우의 도체특성 및 배최장근의 물리화 학적 특성 변화에 미치는 영향은 없었으나, 출하체중 의 감소에 따른 도체 판매가격 저하의 문제가 발생할 수 있다. 이로 인해 거세한우 사육농가에서 개체별 배 합사료 자동급이기를 이용할 경우 기본적인 비육후기 배합사료의 급여수준은 자유채식 수준에 상응하게 해 주는 것이 바람직하고, 단지 초음파 단층촬영을 통해 개체별 육질, 육량 관련 특성(등지방두께, 근내지방도 등)을 고려하여 배합사료의 제한급여가 필요한 개체에 한해서 사료섭취량을 조절해 주는 것이 바람직 할 것 으로 사료된다.

\section{IV. 요 약}

본 연구는 배합사료의 급여방법(군사, 개체별 배합 사료 자동급이) 및 출하월령 (생후 26 및 28개월)이 거 세한우의 발육, 사료섭취량 및 도체특성 변화에 미치 는 영향을 조사하기 위해 수행되었다. 시험구는 생후 26 개월령 출하 군사구 (G26), 개체별 배합사료 자동급 이구(I26), 생후 28개월령 출하 군사구(G28), 개체별 배합사료 자동급이구 (I28)의 4처리로 하여 각 처리당 $7 \sim 8$ 두씩 총 31 두를 완전 임의배치하였다. 비육후기 배 합사료 급여수준은 군사구 (G26 및 G28)는 자유채식, 개체별 배합사료 자동급이구는 개체별로 체중의 $1.7 \%$ 이었다. 비육전기 일당증체량은 군사구들 (G26 및 $\mathrm{G} 28$ )에 비해 개체별 배합사료 자동급이구들 (I26 및 $\mathrm{I} 28)$ 에서 많았으나 $(\mathrm{p}<0.05)$, 비육후기 일당증체량은 개 체별 배합사료 자동급이구들에 비해 군사구들에서 유 의적으로 높았다 $(\mathrm{p}<0.05)$. 비육전기 배합사료 섭취량 은 군사구들에 비해 개체별 배합사료 자동급이구들에 서 많았지만, 비육후기에는 개체별 배합사료 자동급이 구들에 비해 군사구들에서 많은 경향이었다. 배합사료 급여방법 및 출하월령이 거세한우의 도체특성, 육량등 급 및 육질등급에 미치는 영향은 적었다. 배최장근의
전단력 및 연도는 26 개월 출하 시험구들에 비해 28 개 월 시험구들에서 높았다 $(\mathrm{p}<0.05)$. 배최장근의 가열감 량, 보수력, 풍미, 수분, 단백질 및 지방 함량에 대한 사료급여 방법 및 출하월령의 영향은 없었다. 따라서 비육후기 개체별 배합사료의 제한급여가 거세한우의 도체특성에 미치는 영향은 적지만, 출하체중 저하로 농가소득을 감소시킬 수 있으므로 거세한우를 대상으 로 개체별 자동급이기를 이용시 개체특성 (등지방두께, 근내지방도 등)을 고려한 개체별 배합사료 급여수준 설정이 필요한 것으로 판단된다.

\section{V. 인 용 문 헌}

1. Andersen, H. R. and Ingvartsen, K. L. 1984. The influence of energy level, weight at slaughter and castration on growth and feed efficiency in cattle. Livestock Prod. Sci. 11:559-569.

2. AOAC. 1995. Official Methods of Analysis. 16th Ed. Association of Official Analytical Chemists, Washington D.C., U.S.A.

3. Hermesmeyer, G. N., Berger, L. L., Merchen, N. R. and Nash, T. G. 2002. Effects of restricted and ad libitum intake of diets containing wheat middlings on site and extent of digestion in steers. J. Anim. Sci. 80:812-817.

4. Hermesmeyer, G. N., Berger, L. L., Nash, T. G. and Brandt, R. T. 2000. Effects of energy intake, implantation, and subcutaneous fat end point on feedlot steer performance and carcass composition. J. Anim. Sci. 78:825-831.

5. Hicks, R. B., Owens, F. N., Gill, D. R., Martin, J. J. and Strasia, C. A. 1990. Effects of controlled feed intake on performance and carcass characteristics of feedlot steers and heifers. J. Anim. Sci. 68:233-244.

6. Laakkonen, E., Wellington, G. H. and Skerbon, J. W. 1970. Low temperature longtime heating of bovine. I . Changes in tenderness, water binding capacity, $\mathrm{pH}$ and amount of water-soluble component. Journal of Food Science. 35:175-177.

7. Loerch, S. C. 1990. Effects of feeding growing cattle high-concentrate diets at a restricted intake on feedlot performance. J. Anim. Sci. 68:3086-3095.

8. Loerch, S. C. and Fluharty, F. L. 1998. Effects of programming intake on performance and carcass characteristics of feedlot cattle. J. Anim. Sci. 76:371-377.

9. Murphy, T. A., Loerch, S. C. and Dehority, B. A. 1994. The influence of restricted feeding on site and extent of digestion and flow on nitrogenous compounds to the duodenum in steers. J. Anim. Sci. 72:2487-2496. 
10. SAS. 1999. SAS / STAT Software for PC. Release 6.11, SAS Institute, Cary, NC, U.S.A

11. Schackelford, S. D., Wheeler, T. L. and Koohmarmie, M. 1995. Relationship between shear force and trained sensory panel tenderness ratings of 10 major muscles form bos indicus and bos Taurus cattle. J. Anim. Sci. 73:3333-3340.
12. 김영근, 조영무, 최순호, 권응기, 명규호, 강병무, 손삼규. 2003. 거세한우 비육후기 농후사료 제한급이가 성장 및 도체특성에 미치는 영향. 축산시험연구보고서. pp. 720-726.

13. 축산물등급판정소. 2008. 축산물등급판정통계. http:// www.kormeat.co.kr/

(접수일자 : 2008. 10. 24. / 수정일자 : 2009. 2. 9. /

채택일자 : 2009. 2. 11.) 